\title{
Corrigendum
}

Diabetes Metab J 2019;43:381

https://doi.org/10.4093/dmj.2018.0100

pISSN 2233-6079 • eISSN 2233-6087

DIABET\&S \& METABOLISM JOURNAL

\section{Corrigenda: Omission of the Description of Informed Consent}

Editorial Office, Diabetes \& Metabolism Journal

Tel: +82-2-714-9064, Fax: +82-2-714-9084

E-mail: diabetes@kams.or.kr

Out of 2 original articles published in Diabetes \& Metabolism Journal from December 2018 to February 2019, 2 articles lacked the description of informed consent. However, the editorial office had already received the informed consent when all submitted manuscripts were arrived at the office. Therefore, editorial office apologizes readers not checking those ethical issues and publishes corrigendum as follows:

\section{Patterns of Nerve Conduction Abnormalities in Patients with Type 2 Diabetes Mellitus According to the} Clinical Phenotype Determined by the Current Perception Threshold

Park JH, Won JC

Diabetes Metab J 2018;42:519-528. https://doi.org/10.4093/dmj.2018.0068

\section{Note}

INFORMED CONSENT

This study was approved by the Inje University Sanggye Paik Hospital Research Ethics Committee (2017-02-032003). Informed consent was waived by the IRB due to the anonymous nature of the data.

\section{Projection of Diabetes Prevalence in Korean Adults for the Year 2030 Using Risk Factors Identified from}

National Data

Baik I

Diabetes Metab J 2019;43:90-96. https://doi.org/10.4093/dmj.2018.0043

\section{Note}

INFORMED CONSENT

Informed consent was obtained during the process of KNHANES and the study protocol was approved by the Human Subjects Review Committee of Kookmin University (KMU-201512-HR-094).

This is an Open Access article distributed under the terms of the Creative Commons Attribution Non-Commercial License (http://creativecommons.org/licenses/by-nc/4.0/) which permits unrestricted non-commercial use, distribution, and reproduction in any medium, provided the original work is properly cited. 